\title{
THE EFFECT OF ENDOPHYTE (NEOTYPHODIUM UNCINATUM) IN MEADOW FESCUE ON GRASS GRUB LARVAE
}

\author{
A.J. POPAY ${ }^{1}$, R.J. TOWNSEND ${ }^{2}$ and L.R. FLETCHER ${ }^{2}$ \\ ${ }^{1}$ AgResearch, Ruakura Research Centre, Private Bag 3123, Hamilton \\ ${ }^{2}$ AgResearch, Canterbury Science Centre, PO Box 60, Lincoln \\ Corresponding author: alison.popay@agresearch.co.nz
}

\begin{abstract}
Grass grub (Costelytra zealandica) population density, mean larval weight and visible damage were lower in meadow fescue (Festuca pratensis) infected with the endophyte Neotyphodium uncinatum $(\mathrm{E}+)$ than in uninfected meadow fescue $(\mathrm{E}-)$ in an unreplicated field trial. In two bioassays, third instar grass grubs ate all meadow fescue E- roots but significantly less of the E+ roots. Larvae fed E+ roots lost weight at the same rate as unfed control larvae. Larvae given a choice between maize and either E+ or E-meadow fescue in a pot trial consumed $33 \%$ more of the maize in the $\mathrm{E}+$ treatment than in the $\mathrm{E}$ - treatment. Weight gain of larvae in E+ treatments was significantly less than in E- in both the choice and no-choice pot trials, but survival was the same. It was concluded that meadow fescue infected with $N$. uncinatum deters grass grub larval feeding but has no major toxic effects.
\end{abstract}

Keywords: meadow fescue, Neotyphodium uncinatum, endophyte, grass grub, Scarabaeidae.

\section{INTRODUCTION}

Meadow fescue (Festuca pratensis) is naturally infected with a fungal endophyte, Neotyphodium uncinatum. Presence of the endophyte is associated with improved plant performance and drought resistance (Malinowski et al. 1997a, 1997b) and resistance to foliar and root aphids (Schmidt \& Guy 1997). The endophyte produces three loline alkaloid derivatives in abundance, $N$-formylloline, $N$-acetylloline and $N$-acetylnorloline (Justus et al. 1997; Ball \& Tapper 1999), mainly in the above-ground leaf blades and pseudostems but also in the roots (Bush et al. 1993). The loline alkaloids have bioactivity against a range of insects (e.g. Breen 1994), including grass grub (Costelytra zealandica) and porina (Wiseana cervinata) (Popay \& Lane 2000). Other alkaloids with known anti-insect properties, such as lolitrem B, peramine and ergovaline, produced by the endophytes, $N$. lolii in ryegrass (Lolium perenne) and $N$. coenophialum in tall fescue (F. arundinaceae), are not found in meadow fescue infected with $N$. uncinatum.

During late summer and autumn 2000, symptoms of severe grass grub damage were observed in a 2-year-old endophyte-free (E-) meadow fescue pasture at Lincoln, Canterbury. In stark contrast to this, an adjacent endophyte-infected (E+) meadow fescue paddock was considerably more vigorous and showed few visible symptoms of damage. This paper reports the results of sampling these paddocks, and subsequent laboratory and pot trials carried out to investigate the effects of endophyte in meadow fescue on grass grub larvae.

\section{Field trial}

\section{METHODS}

In autumn 1998, two adjacent 0.15 ha paddocks at Lincoln, Canterbury, were sown with an ecotype of meadow fescue selected in Northland. These paddocks had been part of a larger paddock so they had a common 10-year history of being in pasture, with a 
cereal crop prior to establishing the meadow fescue. The soil type was a Wakanui silt loam. The endophyte-infection levels in each sward were determined in 50 tillers taken randomly from each paddock in autumn 1999 and 2000 using a modified immunoblot technique (Gwinn et al. 1991). Pastures were grazed in spring, summer and autumn with separate mobs of hoggets or weaned lambs. In April 2000, ten spade squares (190 $\mathrm{x} 190 \mathrm{~mm}$ ) were taken at random throughout each paddock and the number and stage of development of grass grub larvae in each was recorded. A random selection of 44 larvae from each paddock was weighed, and their weights compared using a Student's T-test.

\section{Bioassay}

In two trials conducted in July and August 2001, the feeding response of grass grub larvae to roots of $\mathrm{E}+$ and $\mathrm{E}$ - meadow fescue and to roots of an annual Italian ryegrass (L. multiflorum) cv. Tama was tested, and weight changes were compared with unfed control larvae. Third instar grass grub were collected from Canterbury pastures several days prior to each trial and held at $4^{\circ} \mathrm{C}$. Larvae were then fed a small piece of fresh carrot $24 \mathrm{~h}$ prior to each trial so that only healthy, feeding larvae were selected for the experiments. Roots of meadow fescue were taken from field-grown plants and those of Tama ryegrass from glasshouse-grown plants. In each trial, eight weighed grass grub were randomly assigned to one of four treatments and placed individually into wells of 24-well Multiwell TM tissue culture plates. After $24 \mathrm{~h}$ without food all larvae, except the unfed controls, were provided with a weighed portion of washed root. Three days later all larvae and remaining root material were again weighed. The tissue culture plates were enclosed in plastic bags with damp paper towels and placed in an incubator at $15^{\circ} \mathrm{C}$. Data were analysed with an analysis of variance.

\section{Pot Trial}

Pre-germinated meadow fescue seed was planted into a commercial organic potting mix in polystyrene planter boxes in December 2001. The plants were retained in a shadehouse under daily automatic overhead watering. In February, all plants were trimmed to $5 \mathrm{~cm}$ and checked for the presence of endophyte by microscopic examination of leaf sheath tissue stained in aniline blue.

In the choice trial, maize was paired with either endophyte-free or endophyte-infected meadow fescue. This pairing utilised the natural difference in carbon isotope composition between a $\mathrm{C} 4$ grass (maize) and a C3 grass (meadow fescue), thus allowing an estimation of the proportion of maize consumed when there was either an E+ or E- plant present and consequent quantification of the level of deterrency exerted by the endophyte. The paired treatments were set up in late February by planting germinated maize seed together with either E+ or E- plants in black plastic rectangular containers $(320 \times 140 \times 120 \mathrm{~mm})$ containing a $20 \mathrm{~mm}$ base of washed sand and then two thirds filled with a coarsely sieved field soil. There were 10 replicate pairings of maize with each endophyte treatment. A plastic partition was placed in the soil in the centre of the container to reduce intermingling of maize and meadow fescue roots.

A no-choice trial was set up at the same time as the choice trial. This trial consisted of five replicate plants of maize, E- or E+ meadow fescue placed individually into $150 \mathrm{~mm}$ diameter plant pots in the same medium used in the choice trial. Both trials were maintained in a shadehouse for 1 month under automatic watering.

On 26 March, all pots were weeded thoroughly and the plastic partitions were removed from the choice trial containers. Third instar grass grub larvae collected from a perennial ryegrass/white clover pasture at the Tokanui Research Station the previous day were sorted and weighed in groups of five larvae for the choice trial and three larvae for the no-choice trial. Larvae were placed on the soil surface midway between the plants in the choice trial and around the base of the plants in the no-choice test in the late afternoon. After an hour, three larvae in separate pots in the no-choice trial had failed to bury themselves so they were removed, weighed and replaced with a fresh larva of known weight. Thereafter, the trials were watered with a hand-held hose every 2-3 days or as necessary and kept weed free.

After 7 weeks all pots were sorted by hand and the number of larvae recorded together with their position (i.e. under maize or meadow fescue) in the choice trial. Larvae from 
each pot were weighed as a group and then frozen, and roots of each plant were washed carefully to remove all soil, before both were oven dried at $80^{\circ} \mathrm{C}$ for $48 \mathrm{~h}$. Samples of larvae and roots were finely ground and the delta ${ }^{13} \mathrm{C}$ content estimated on a Dumas elemental analyser interfaced to an isotope mass spectrometer. The proportion of grass grub diet that consisted of maize in the two treatments in the choice trial was estimated from the carbon isotope $\left(\delta^{13} \mathrm{C}\right)$ content of the larvae using the formula:

$\left(\delta^{13} \mathrm{Cmf}-\delta^{13} \mathrm{Cgg} / \delta^{13} \mathrm{Cmf}-\delta^{13} \mathrm{ma}\right) * 100$

where: $\mathrm{mf}=$ grass grub fed meadow fescue only

$\mathrm{gg}=$ grass grub from each replicate from the choice trial

$\mathrm{ma}=$ grass grub fed maize only

An analysis of variance was carried out on data pertaining to larval weights and proportion of maize in the diet, the latter after log transformation. A Student's T-test was used to directly compare larval weight in the E+ and E- treatments in the no-choice trial. The proportion of larvae found under maize was analysed using a logistic regression model in GenStat.

\section{Field trial}

\section{RESULTS}

In the E+ meadow fescue, $93 \%$ of tillers contained endophyte in both 1999 and 2000, while no endophyte infection was found in tillers from the E- treatment. Grass grub larval density was $413 / \mathrm{m}^{2}$ in the E- meadow fescue paddock and $258 / \mathrm{m}^{2}$ in the E+. The populations were comprised of $91 \%$ third instars in the E+ treatment and $94 \%$ in the Epaddock. Mean larval weights from each paddock were $157( \pm 5.9)$ and $123( \pm 6.7) \mathrm{mg}$ $(\mathrm{P}<0.001)$ for the $\mathrm{E}-$ and $\mathrm{E}+$ treatments respectively.

\section{Bioassay}

Mean weights of larvae at the beginning of each trial were $133 \mathrm{mg}$ for Bioassay 1 and $131 \mathrm{mg}$ for Bioassay 2 with no difference between treatments. After 3 days, larvae had consumed all or almost all of the $\mathrm{E}$ - and Tama roots offered but significantly less $(\mathrm{P}<0.05)$ of the E+ roots (Table 1). Larvae in the E+ and unfed treatments had a mean weight loss whereas larvae in the E- and Tama treatments gained weight. The differences between these two sets of treatments were significant for both assays.

TABLE 1: Mean weight (mg) of grass grub larvae and root consumption in Bioassay 1 and 2.

\begin{tabular}{lccccc}
\hline & \multicolumn{2}{c}{ Larval weight } & & \multicolumn{2}{c}{ Root consumption } \\
\cline { 2 - 3 } \cline { 5 - 6 } Treatment & Initial & Change & & Initial weight $(\mathrm{mg})$ & \%Consumed \\
\hline Bioassay 1 & 134 & 1.3 & & 250 & 100 \\
MF E- & 134 & -4.8 & & 255 & 41 \\
MF E + & 132 & 4.4 & & 248 & 100 \\
Tama & 133 & -3.4 & & - & - \\
Unfed & 5.1 & 1.5 & & & 4.5 \\
SED & 129 & 6.1 & & 326 & 100 \\
Bioassay 2 & 131 & -3.8 & & 328 & 66 \\
MF E- & 129 & 5.4 & & 324 & 96 \\
MF E + & 133 & -2.5 & & - & - \\
Tama & 4.7 & 3.6 & & & 5.1 \\
Unfed & & & &
\end{tabular}

\section{Pot trials}

Mean initial weight of larvae was similar for each treatment in both the choice and no-choice trials. Over all treatments, mean survival during the trial was $85 \%$ in the choice trial and $82 \%$ in the no-choice trial with no difference between treatments (Table 
2). Differences in weight gain of larvae in the no-choice trial were not quite significant $(\mathrm{P}=0.059)$ when analysed by ANOVA but a t-test showed a significantly lower weight gain in the $\mathrm{E}+$ treatment than in the $\mathrm{E}$ - treatment (Table 2). In the choice trial, larval weight was significantly lower in the maize/E+ treatment than in the maize/E- treatment.

TABLE 2: Mean weight gain (mg) and survival of grass grub larvae in the choice and no-choice pot trials.

\begin{tabular}{lccccc}
\hline & \multicolumn{2}{c}{ No-Choice } & & \multicolumn{2}{c}{ Choice } \\
\cline { 2 - 3 } \cline { 5 - 6 } Treatment & \% Survival & Weight gain & & \% Survival & Weight gain \\
\hline MF E-1 & 80 & 24 & & 88 & 27 \\
MF E+ & 87 & 4 & & 82 & 12 \\
Maize & 80 & 14 & & & 3.1 \\
SED & & 7.1 & &
\end{tabular}

${ }^{1} \mathrm{MF}=$ meadow fescue, $\mathrm{E}-$ =endophyte-free, $\mathrm{E}+$ =endophyte infected.

The distribution of larvae under maize or meadow fescue was not significantly different with $68 \%$ of larvae found under maize in the maize/E+ treatment plant and $48 \%$ under maize in the maize/E- treatment. Consumption of maize was significantly higher $(\mathrm{P}<0.001)$ in the presence of $\mathrm{E}+$ than in the presence of $\mathrm{E}-$. Given a choice of maize or $\mathrm{E}+$, it was estimated from the delta ${ }^{13} \mathrm{C}$ composition of the larvae that $49 \%$ of the diet consisted of maize whereas in the maize/E- treatment the proportion of maize consumed was $17 \%(\mathrm{SED}=5.8)$.

\section{DISCUSSION}

The observations made in the field trial at Lincoln suggested that the endophyte $N$. uncinatum in meadow fescue had a protective effect against grass grub which prevented major damage to the pasture from this pest. The activity of the endophyte was confirmed in both the bioassays and the pot trials, showing that $N$. uncinatum in meadow fescue deters larval feeding. However, the endophyte was not completely repellent to the larvae and some feeding on the E+ roots occurred in the bioassays and the choice pot trial. Despite this feeding, larvae suffered weight loss or significant reductions in weight gain in these trials, even in the presence of an alternative food source such as maize. In the bioassay, the weight loss was equivalent to that of the unfed control larvae. These results suggest that $N$. uncinatum may be having more than just a deterrent effect on the larvae. However, in the no-choice pot trial the survival of grass grub over the 7-week period of the trial was not reduced in the E+ treatment as might be expected if the endophyte was toxic to the larvae. Over a longer period of time the endophyte may increase grass grub mortality as probably occurred in the field trial where there were considerably fewer larvae in the E+ paddock than in the E-, but this could be attributed to poor nutrition of larvae deterred from feeding and is not necessarily indicative of toxicity. No major developmental delays were apparent in the field since both populations were comprised mainly of third instars at the time of sampling. These results cannot be explained by the presence of alternative food sources for the larvae in the E+ pasture since over $95 \%$ of this sward consisted of meadow fescue (Fletcher et al. 2000).

The deterrency and apparent lack of a directly toxic effect of $N$. uncinatum on grass grub is consistent with the known effects of loline alkaloids on this insect (Popay \& Lane 2000). These alkaloids also deter feeding by larvae of the Japanese beetle (Popillia japonica) (Patterson et al. 1991). Like N. uncinatum, N. coenophialum in tall fescue produces loline alkaloids and several studies have been carried out on the effects of this plant/endophyte combination on root-feeding scarab grubs but consistent effects have not been demonstrated. Separate greenhouse trials have shown N. coenophialum infection can affect survival and weight gain in Japanese beetle, grass grub and southern masked chafer (Cyclocephala lurida) (Potter et al. 1992; Popay et al. 1993) and also increase the tolerance of tall fescue to herbivory (Crutchfield \& Potter 1995). Evidence for the effect 
of endophyte on grub larvae in the field is more equivocal. Murphy et al. (1993) found fewer scarabaeid grubs in E+ tall fescue than in E- in one of two field trials, but in several other trials no measurable effect of endophyte-infected tall fescue on larval populations of Japanese beetle was found (Oliver et al. 1990; Potter et al. 1992; Davidson $\&$ Potter 1995). Concentrations of lolines in the plants need to be high enough to overcome the feeding stimuli that are present in order for bioactivity to occur. E+ meadow fescue tends to have higher concentrations of loline alkaloids than tall fescue (Ball \& Tapper 1999) which may explain the clear effect of E+ meadow fescue on grass grub both in the field and laboratory described in this paper compared with the apparently inconsistent effects of E+ tall fescue on root-feeding scarabaeid larvae.

\section{ACKNOWLEDGEMENTS}

Our thanks to Alan Stewart, Pyne Gould Guinness Ltd, for provision of seed; Joanne Jensen for technical assistance; Katarina Domijan for statistical analysis; and to the Stable Isotope Unit and Professor Warwick Silvester of Waikato University for assistance with carbon isotope analysis. The support and funding of Meat NZ and the Foundation for Research, Science and Technology (Contract No. C10X0228) is gratefully acknowledged.

\section{REFERENCES}

Ball, O.J-P.; Tapper, B.A. 1999: The production of loline alkaloids in artificial and natural grass/endophyte associations. Proc. 52nd N.Z. Plant Protection Conf.: 264-269.

Breen, J.P. 1994: Acremonium endophyte interactions with enhanced plant resistance to insects. Ann. Rev. Entomol. 39: 401-423.

Bush, L.P.; Fannin, F.F.; Siegel, M.R.; Dahlman, D.L.; Burton, H.R. 1993: Chemistry, occurrence and biological effects of saturated pyrrolizidine alkaloids associated with endophyte-grass interactions. Agric. Eocsyst. Environ. 44: 81-102.

Crutchfield, B.A.; Potter D.A. 1995: Damage relationships of Japanese beetle and southern masked chafer (Coleoptera: Scarabaeidae) grubs in cool season turfgrasses. J. Econ. Entomol. 88: 1049-1056.

Davidson, A.W.; Potter D.A. 1995: Response of plant-feeding, predatory, and soilinhabiting invertebrates to Acremonium endophyte and nitrogen fertilisation in tall fescue turf. J. Econ. Entomol. 88: 376-379.

Fletcher, L.R.; Popay, A.J.; Stewart, A.V.; Tapper, B.A. 2000: Herbage and sheep production from meadow fescue with and without the endophyte Neotyphodium uncinatum. In: Paul, V.H.; Dapprich, P.D. ed. 4th Int. Neotyphodium/Grass Interactions Symp. Universitat-Gesamthochschule, Paderborn, Soest, Germany. Pp. 447-453.

Gwinn, K.D.; Colins-Shephard, M.H.; Reddick, B.B. 1991: Tissue-print immunoblot, an accurate method for the detection of Acremonium coenophialum in tall fescue. Phytopath. 81: 747-748.

Justus, M.; Witte, L.; Hartman, T. 1997: Levels and tissue distribution of loline alkaloids in endophyte-infected Festuca pratensis. Phytochem. 44: 51-57.

Malinowski, D.; Leuchtmann, A.; Schmidt, D.; Nosberger, J. 1997a: Growth and water status in meadow fescue is affected by Neotyphodium and Phialophora species endophytes. Agron. J. 89: 673-678.

Malinowski, D.; Leuchtmann, A.; Schmidt, D.; Nosberger, J. 1997b: Symbiosis with Neotyphodium unicnatum endophyte may increase the competitive ability of meadow fescue. Agron. J. 89: 833-839.

Murphy, J.A.; Sun S.; Betts L.L. 1993: Endophyte-enhanced resistance to billbug (Coleoptera: Curculionidae), sod webworm (Lepidoptera: Pyralidae) and white grub (Coleoptera: Scarabaeidae) in tall fescue. Environ. Entomol. 22: 699-703. 
Oliver, J.B.; Pless C.D.; Gwinn K.D. 1990: Effect of endophyte, Acremonium coenophialum in 'Kentucky 31' tall fescue, Festuca arundinacae, on survival of Popillia japonica. In: Quisenberry, S.S.; Joost, R.E. ed. Proc. Int. Symp. Acremonium/Grass Interactions. Louisiana Agric. Expt Station, Baton Rouge, LA, USA. Pp. 173-175.

Patterson, C.G.; Potter, D.A.; Fannin F.F. 1991: Feeding deterrency of alkaloids from endophyte-infected grasses to Japanese beetle grubs. Entomol. Exp. Appl. 61: 285289.

Popay, A.J.; Mainland R.A.; Saunders C.J. 1993: The effect of endophytes in fescue grass on growth and survival of third instar grass grub larvae. In: Hume, D.E.; Latch, G.C.M; Easton, H.S. ed. Proc. 2nd Int. Symp. Acremonium/Grass Interactions. Palmerston North, New Zealand. Pp. 174-176.

Popay, A.J.; Lane, G.A. 2000: The effect of crude extracts containing loline alkaloids on two New Zealand insect pests. In: Paul, V.H.; Dapprich, P.D. ed. 4th Int. Neotyphodium/Grass Interactions Symp. Universitat-Gesamthochschule, Paderborn, Soest, Germany. Pp. 471-475.

Potter, D.A.; Patterson C.G.; Redmond, C.T. 1992: Influence of turfgrass species and tall fescue endophyte on feeding ecology of Japanese beetle and southern masked chafer grubs (Coleoptera: Scarabaeidae). J. Econ. Entomol. 85: 900-909.

Schmidt, D.; Guy, R. 1997: Effects of the presence of the endophyte Acremonium uncinatum and of an insecticide treatment on seed production of meadow fescue. Revue-Suisse-d'Agric. 29: 97-99. 